\title{
ANTIBACTERIAL TEST OF PANGIUM (Pangium edule Reinw) EXTRACT AGAINST THE GROWTH OF FISH SPOILAGE BACTERIA
}

\author{
Endang Sri Heruwati ${ }^{1)}$, Lily Ismaini ${ }^{21}$, and Wibowo Mangunwardoyo ${ }^{3)}$ \\ 1) Researcher at Research Center for Marine and Fisheries Product Processing and Biotechnology-Petamburan, Jakarta \\ 2) Researcher at National Research Institute of Indonesia, Kebun Raya Cibodas \\ 3) Lecturer at University of Indonesia, Pascasarjana MIPA, Depok \\ Received April 20-2009; Received in revised form September 16-2009; Accepted October 23-2009
}

\begin{abstract}
An antibacterial test was conducted on fresh and fermented Pangium edule Reinw. Seed extracts against gram positive and negative spoilage bacteria associated with fish. Seed extraction was carried out by maceration with water, water-ethanol (1:1), and n-hexane. Antibacterial activities were determined by an agar diffusion method. Water extract of fresh Pangium edule seed inhibited the growth of gram positive and negative bacteria at concentrations of $40-80 \mathrm{mg} / \mathrm{mL}$, water-ethanol extract inhibited the growth of gram positive and negative bacteria at concentrations of $30-80 \mathrm{mg} / \mathrm{mL}$, while nhexane extract showed no inhibition. On the other hand, extract of fermented Pangium edule seed using water, water-ethanol, and n-hexane showed no antibacterial activity against gram positive and negative bacteria. The minimum inhibitory concentration values of fresh Pangium edule seed water extract were $3.49-11.73 \mathrm{mg} / \mathrm{mL}$, mostly effective against Pseudomonas fluorescens. Meanwhile, the minimum inhibitory concentration of water-ethanol extract were $6.04-10.54 \mathrm{mg} / \mathrm{mL}$, mostly effective against Enterobacter aerogenes, Alcaligenes eutrophus, and Staphylococcus aureus.
\end{abstract}

KEYWORDS: antibacterial activity, agar diffusion method, gram positive and fish spoilage bacteria, minimum inhibitory concentration, Pangium edule Reinw

\section{INTRODUCTION}

Many places in Indonesia are not properly facilitated by basic infrastructures so that in remote areas but fish is highly produced, problems of quantity and quality loss arise due to the lack of ice needed to preserve the fish. To overcome this, fishermen use fresh pangium (Pangium edule Reinw) seed, called picung, to preserve fish traditionally for many decades. Considering its biochemical properties, pangium has a great challenge as a natural preservative, especially for fish and fish products. The lack in quantity, the high price, and the low quality of ice, are known as reason in promoting the misuses of such illegal preservatives like formalin in fish handling in remote areas (Heruwati et al., 2004; Sampurno, 2006). The benefits of pangium for fish handling are not only attributed to its anti-bacteria and antioxidant properties, but pangium is also believed in producing typical flavor on fish and fish product.

Some studies revealed that pangium contains many substances such as flavoring agent, cyanide acid (Heyne, 1959; Bishop, 1997), antioxidant (Anwar, 1992; Panghegar, 1990; Adidjaja, 1991; Romlah, 1992), tannin and antimicrobial agents including hidnocarpic acid, and chaulmogric acid (Hilditch \& Williams, 1964). The cyanide acid is believed to be a derivative product of gynocardine glucosides by the role of gynocardase, while hidnocarpic acid (2 cyclopentene 1 undecanoic $/ \mathrm{C}_{16} \mathrm{H}_{28} \mathrm{O}_{2}$ ) and choulmogric acid (2 cyclopentene 1 tridecanoic/ $\mathrm{C}_{18} \mathrm{H}_{32} \mathrm{O}_{2}$ ) are unsaturated cyclic fatty acids as the acidification product of oleic and linoleic acid contained in the kernel. Pangium also contains polar and nonpolar antioxidants. The nonpolars were á-, ã-, and ä-tocotrienol, though dominated by ã-tocotrienol (Puspitasari-Nienaber et al., 1994). The antioxidant content is reduced during initial phase of seed germination and some of ã-tocotrienol change to áand ä-tocotrienol. However, when the hypocotyls synthetize the chlorophyl, the tocotrienols increased again and at the same time, the tocoferol is synthetized. Or the other hand, the polar antioxidants are possibly carboxylic acid and sugars, which is believe to be a glycon of phenolic conjugate. The total phenolic contents as well as the antioxidant activity of pangium kernel are increased during seed germination. The antioxidant might protect the cell from potential oxidation-induces deterioration (Andarwulan et al., 1999).

Experiment using chopped pangium seed mixed with granular salt, and overspread on the gutted mackerel fish (Rastrelliger brachysoma) at ratio of 2 , 4 , and $6 \%$ kernel and 2 and $3 \%$ salt (w/w to fish weight) revealed that pangium was significantly reduced the $\mathrm{pH}$ and TVB content of fish, although it had no effect on other parameter assessed. At the same time, salt also showed a significant effect on both TVB content and the number of $\mathrm{H}_{2} \mathrm{~S}$ producing bacteria. However, $\mathrm{pH}, \mathrm{TVB}$ content as well as number 
of enteric and $\mathrm{H}_{2} \mathrm{~S}$ producing bacteria increased during fish storage. Sensory evaluation resulted that from the texture, odor and flavor point of view, treatments with $2 \%$ pangium (whether mixed with 2 or $3 \%$ salt) was rejected at day- 6 , while the one with pangium $6 \%$ (with 2 or $3 \%$ salt), and combination of $4 \%$ pangium with $3 \%$ salt was still accepted by the panelists at day-9. Nevertheless, treatments with high content of pangium were not preferred by the panelists due to the fish appearance which were rather brownish in color. This undesirable color may be produced by the reaction between tannin (tannic acid) with ferric compound from fish meat (myogiobine). The tannic acid contained in fish were between $16.7-23.7 \mathrm{ppm}$ at initial and 7.7-11.0 ppm at the end of experiment; while for cyanide, the content in fish were between 20.6$44.4 \mathrm{ppm}$ at initial and 2.5-19.2 ppm at the end of experiment depending on the amount of pangium added (Heruwati et al., 2007).

Though it has been proved both by experiments and by commercial practices that pangium could prolong the shelfife of fish, yet, it still very limited information available on what active substances contained in pangium that responsible in fish preservation, and how long they could delay the spoilage of fish. For this purpose, a study was conducted on the antibacterial activity of water, waterethanol, and $n$-hexane extracts of fresh and fermented pangium against some species of bacteria responsible in fish spoilage. It was expected that based on resulted information on extract that has highest preservative activity, experiment could be followed by isolation, characterization, and purification of the active substances. In the long run, the production of natural preservative for fresh fish could be realized.

\section{MATERIALS AND METHODS}

Ripe pangium (Pangium edule Reinw) fruits were collected from Pabuaran, Cileungsi, Bogor. The seeds then were drawn out and washed with water. Fermented seeds were made by boiling the seed for $6 \mathrm{hrs}$, followed by wrapping in plastic bag and keeping at room temperature for about 40 days.

Two species of gram positive bacteria i.e. Micrococcus luteus, and Staphylococcus aureus, six species of gram negative i.e. Alcaligenes eutrophus, Enterobacter aerogenes, Flavobacterium gleum, Pseudomonas filorescens, Salmonella typhimurium, and Serratia marcescens were used in this experiment. These cultures were obtained from Microbiological Laboratory of Research Institute for Marine and Fisheries Product Processing and
Biotechnology, Jakarta and Microbiological Laboratory of the Bandung Institute of Technology, Bandung.

Chioramphenicol (Indofarma) at concentration of $10 \mathrm{mg} / \mathrm{mL}$ was used as a positive control, while water and water-ethanol (1:1) and n-hexane were used as negative control. Nutrient Agar (NA) (Difco) was used as the growth medium for the cultures, and Mueller Hinton Agar (MHA) (Difco) was used in antibacterial test.

\section{Preparation of Pangium Extracts}

Fresh and fermented pangium seeds were cleaned and washed, then the shells were cracked to get the kernel. The kernel was homogenized and freeze-dried at $-40^{\circ} \mathrm{C}$ followed by grinding them into powder. Extraction was done by macerating $200 \mathrm{~g}$ of fresh or fermented pangium powder in $1,000 \mathrm{~mL}$ of distilled water by shaking at $30 \mathrm{rpm}$ for $3 \times 24 \mathrm{hrs}$. After filtration using Whatman paper no.42, the filtrate was dried using vacuum evaporator at 72 mbar to obtain crude water extract. After filtration, the residue was collected and remacerated using $1,000 \mathrm{~mL}$ of mixture of waterethanol (1:1) with the same procedure as water extraction. Filtrate of the later extraction was dried by using vacuum evaporator at 175 mbar to get crude water-ethanol extract. The residue of second extraction was then remacerated using $1,000 \mathrm{~mL} \mathrm{n}$ hexane by the same procedure. In this last extraction, evaporation of the filtrate was done at $335 \mathrm{mbar}$ to get crude $n$-hexane extract. All crude extracts were then freeze-dried, weighed, and kept in capped bottle until used (Harborne, 1998; Andarwulan et al., 1999).

\section{Preparation of Test Culture}

All cultures were grown at slanted NA for $24 \mathrm{hrs}$ at $37^{\circ} \mathrm{C}$, an ose of each culture was then grown in 20 $\mathrm{mL}$ of nutrient broth, incubated in a shaking water bath at $160 \mathrm{rpm}$, for $24 \mathrm{hrs} 37^{\circ} \mathrm{C}$. The optical density was measured using spectrophotometer at ë $600 \mathrm{~nm}$ to get an absorbance of $0,5-0,6$. To make sure that $a$ total number of $10^{6}-10^{8} \mathrm{cfu} / \mathrm{mL}$ had been achieved, counting of the total bacteria using Mc Farland method (DG of Drug \& Food Control, 1995) was also conducted.

\section{Antibacterial Test}

Each $800 \mathrm{~g}$ of freeze-dried crude extract was dissolved in its appropriate solvent (i.e. water, waterethanol, n-hexane), added with phosphate buffer at $\mathrm{pH} 7$ to make a stock solution containing $80 \mathrm{mg}$ extract/mL. Each stock solution was then diluted into 
test solution at concentration of $10,20,30,40,50$, 60,70 , and $80 \mathrm{mg} / \mathrm{mL}$ (DG of Drug \& Food Control, 1995).

Antibacterial test was conducted using agar plate diffusion method. Twenty $\mu \mathrm{L}$ of test bacteria were inoculated into test tubes containing $15 \mathrm{~mL}$ of $\mathrm{MHA}$ medium, homogenized, and poured into sterile plates. Sterile paper disks ( $6 \mathrm{~mm}$ in diameter) that had been dipped in $20 \mathrm{iL}$ of pangium extract at concentration of $10,20,30,40,50,60,70$, and $80 \mathrm{mg} / \mathrm{mL}$ were then put onto the surface of solid MHA plates which had been cultured by tested bacteria, and incubated at $37^{\circ} \mathrm{C}$ for $24 \mathrm{hrs}$. Six paper disks were put in each plate, two of them were positive control (chloramphenicol at concentration of $10 \mathrm{mg} / \mathrm{mL}$ ) and negative control (appropriate solvent), respectively. The inhibition area were assessed by measuring the diameters of clear zone surrounding the paper disks (DG of Drug \& Food Control, 1995). Experiment was conducted using 3 replications.

Antibacterial activity of the extract was determined based on the clear zone area. Low activity is the one having clear zone of less than $5 \mathrm{~mm}$, medium activity is between $5-10 \mathrm{~mm}$, while strong activity is between $11-20 \mathrm{~mm}$, and very strong is the one having clear zone between 21-30 mm (Morales et al., 2003 in Ismaini, 2007).

\section{Minimum Inhibition Concentration}

Minimum inhibition concentration was calculated using the linear regression between Mo (concentration of pangium extract te.st solution) and $x^{2}$ (square of inhibition area) which crossed the ordinat at MT. MIC was determined as anti-In of $1 / 4 \times$ Mt (Bloomfield, 1991 in Nuraida et al., 2000).

\section{RESULTS AND DISCUSSIONS}

\section{Pangium Seed Composition and Yield of Pangium Extracts}

Fresh pangium seed contains about $52 \%$ water, $16 \%$ fat, $18 \%$ carbohydrate, and $13 \%$ protein. There are also some minerals contained in the fresh seed (Heruwati et al., 2007).

Out of $200 \mathrm{~g}$ of raw material, extraction of fresh pangium seed using water yielded $4.93 \mathrm{~g}$ powder, while extraction using water-ethanol and $n$-hexane yielded 5.45 and $1.08 \mathrm{~g}$ powder respectively. On the other hand, the yield of water, water-ethanol, and $n-$ hexane extract of $200 \mathrm{~g}$ of fermented seed were 15.43 , 20.53 , and $1.13 \mathrm{~g}$ powder respectively. For both fresh and fermented seeds, extraction using water-ethanol gave the highest yield because the solvent effectively drawn out polar and semipolar substances contained in the pangium seed such as the flavonoids, phenol, tannin, and perhaps small amount of terpenoids, saponins, alcaloids, and steroids. These substances are produced as a biodegradation of fat and protein contained in the seed (Harborne, 1998). Claeson et al. (1998); Andarwulan et al. (1999) stated that waterethanol is a good solvent to extract the polyphenols, phenols, glycocides, and flavonoids from plants. According to Dicko et al. (2006), phenolic substances are easily dissolved in polar solvent, due to its aromatic ring having one or more hydroxyl group (s).

Water extraction of fresh and fermented seed yielded less of extract because as a polar solvent, water could only pulled out polar substances such as flavonoids and tannin, as well as anionic substances, such as thiocianates, nitrates, chlorides, and sulphates. Wahyono (2004) found that extraction of Scurrula atropurpurea with water could drawn out the flavonoids. On the other hand, extraction of fresh and fermented pangium seed with $\mathrm{n}$-hexan produced the least yield because $n$-hexane is a non-polar solvent so it only could extract the non polar substances especially those containing oil and fat such as triterpenoids (kamphor, linalool) and steroids.

\section{Inhibition Rate of Each Extract Against the Growth of Gram Positive and Negative Bacteria}

\section{a. Water extract of fresh and fermented pangium seed}

Water extract of fresh pangium seed could inhibit the growth of gram positive bacteria (Staphylococcus aureus and Micrococcus luteus) at concentration of $40-80 \mathrm{mg} / \mathrm{mL}$, with the diameter of inhibition zone of $5.00-8.50 \mathrm{~mm}$ for $S$. aureus and 0.33-1.33 $\mathrm{mm}$ for $M$. luteus (Appendix 1). This inhibition was possibly due to the antibacterial substances contained in the extract such as phenols, flavonoids, alkaloids, tannins, and anionic substances like thiocianates, nitrates, chlorides, and sulphates. The mechanism of bacterial inhibition by phenols is by bonding of hydroxyl group of phenol with bacterial protein membrane, leading to the disruption of membrane permeability, affecting the electron transport system, and the rupture of peptidoglycan layer of bacterial cell walls. The inhibition mechanism of anionic substances to bacterial growth is through the inhibition of extracellular enzyme during oxidation process of disulphide bonds (El Astal et al., 2005). However, water extract at concentration of $10-30 \mathrm{mg} / \mathrm{mL}$ could not inhibit the growth of $S$. aureus and $M$. luteus due to low toxicity of the extract so it couldn't be able to 
rupture the peptidoglycan layer of bacterial cell membrane.

Water extract of fresh seed could inhibit the growth of gram negative bacteria, Alcaligenes eutrophus and Enterobacter aerogenes at concentration of $30-80 \mathrm{mg} /$ $\mathrm{mL}$, with inhibition zone diameter of 3.33-2.00 mm for $A$. eutrophus, and 0.16-1.67 mm for $E$. aerogenes, while for Serratia marcescens, Pseudomonas fluorescens, Flavobacterium gleum, and Salmonella typhimurium the effective doses were $40-80 \mathrm{mg} / \mathrm{mL}$, giving zone diameter of $0.83-2.67 \mathrm{~mm}, 1.00-1.17 \mathrm{~mm}$, 0.50-1.17 mm, and 1.00-3.00 mm for S. marcescens, $P$. fluorescens, F. gleum, and $S$. typhimurium respectively (Appendix 2). The mechanism of gram negative bacteria inhibition by phenols was possibly because the diffusion of phenol into the surface of the bacterial cell, especially at hydrophobic lipid bilayer, therefore the hydrolytic enzyme in lipopolysaccharide and the phospholipid layer were inhibited resulting in the loss of the protection of bacterial cytoplasmic membrane.

For the fermented seed, water extract at concentration of $10-80 \mathrm{mg} / \mathrm{mL}$ didn't show any antibacterial activity (Appendix 1 and 2) against gram positive ( $S$. aureus and $M$. luteus) and gram negative bacteria ( $A$. eutrophus, E. aerogenes, S. marcescens, $P$. fluorescens, F. gleum, and S. typhimurium). This is presumably due to the decomposition of antibacterial substances or related enzymes during the boiling of the seed before fermentation process.

b. Water-ethanol extract of fresh and fermented pangium

Water-ethanol (1:1) extract of fresh pangium could inhibit the growth of gram positive $S$. aureus at concentration of $30-80 \mathrm{mg} / \mathrm{mL}$ with zone diameter of 7.00-4.67 mm (Figure 1) and $M$. luteus at concentration of $40-80 \mathrm{mg} / \mathrm{mL}$ with zone diameter of 1.00-3.00 mm (Appendix 1). The inhibition mechanisms were possibly similar to the inhibition of water extract because the polarity of both solvents were nearly similar, so that the same substances were also extracted. Dicko et al. (2006) reported that proantocyianidine (condensed tannin) is toxic to microorgànism by inhibition of hydrolytic enzymes, and inactivation of protein transport in envelope cell. According to Gilbert (1984) biosynthetic disturbance of peptidoglycan is also due to the diffusion of toxic phenolic into the cell membrane, causing increase in permeability, thus resulted in the increase of intracellular pressure to peptidoglycan. The diameter of clear zones of water-ethanol extract treatments on $S$. aureus was wider than that of $M$. Iuteus i.e. 5.00$8.50 \mathrm{~mm}, 7.00-14.67 \mathrm{~mm}$, and 0.33-1.33 mm, 1.00$3.00 \mathrm{~mm}$ presumably because $S$. aureus is more sensitive to phenols, alkaloids and flavonoids than $M$. luteus. El Astal et al. (2005) revealed that $S$. aureus was very sensitive to ethanol extract of Thymus vulgaris and Salvia officinalis at concentration between $2.5-40.0 \mathrm{mg} / \mathrm{mL}$.

Water-ethanol extract of fresh pangium could inhibit the growth of gram negative $E$. aerogenes and $A$. eutrophus at concentration of $30-80 \mathrm{mg} / \mathrm{mL}$ with zone diameter of 7.00-16.67 mm for E. aerogenes, and 7.00$12.00 \mathrm{~mm}$ for $A$. eutrophus. This extract also inhibit F. gleum, S. typhimurium, P. fluorescens, and $S$. marcescens at concentration of $40-80 \mathrm{mg} / \mathrm{mL}$, with zone diameter of 1.33-2.33 mm for $F$. gleum, 1.00$3.00 \mathrm{~mm}$ for $S$. typhimurium, $1.00-3.00 \mathrm{~mm}$ for $P$. fluorescens, and 1.00-2.00 mm for $S$. marcescens (Appendix 2). Pimia et al. (2001) found that ethanol extract of Fragaria sp. inhibited Escherichia coli and

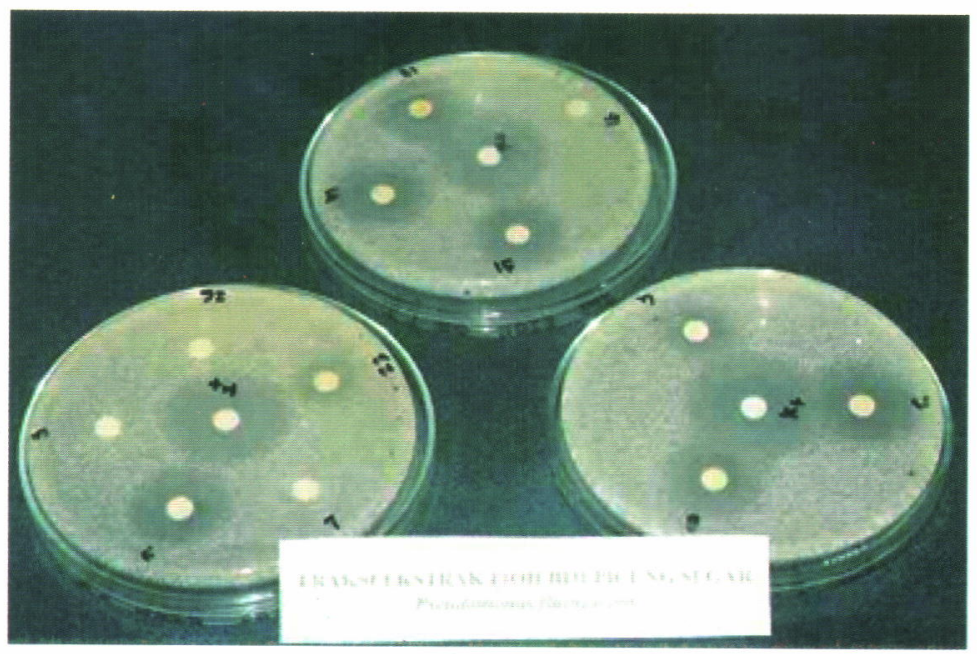

Figure 1. The inhibition zone of water-ethanol extract of pangium seed against $S$. aureus. 
S. typhi, while El Astal et al. (2005) revealed that ethanol extract of Thymus vulgaris and Salvia aucheri inhibited $P$. aeruginosa.

Water-ethanol extract of fermented pangium seed could inhibit the growth of gram positive $S$. aureus and gram negative $S$. marcescens at concentration of $70-80 \mathrm{mg} / \mathrm{mL}$ with zone diameter of $5.33-6.00 \mathrm{~mm}$, and 2.67-3.50 $\mathrm{mm}$ respectively, but not at concentration of $10-60 \mathrm{mg} / \mathrm{mL}$ (Appendix 1 and 2). The mechanism of inhibition was presumably because the fermented seed extract contains antioxidants which could perform as an antibacteria. Andarwulan ot al. (1999); Anwar (1992) revealed that fermented pangium contained many antioxidants such as tocopherols, tocotrienols, and antioxidants originated from primary amine groups and aromatic (benzene) groups.

c. n-hexane extract of fresh and fermented pangium

It was noted from the experiment that $n$-hexane extract of fresh and fermented pangium at all concentration could not inhibit all bacteria tested. This probably because the extracts contain fats and fatty acid substances, that might hindered the diffusion of antibacterial agents into the peptidoglycan of the cell wall of gram positive bacteria or hydrophobic lipid bilayer of the gram negative bacteria. Moshi \& Mbwambo (2005) also found that non polar extract of Terminalia sericea could not suppress the growth of $S$. aureus, S. typhii, and $P$. aeruginosa. Similar to this, Priyono (2004); Indriyanto (2004) reported that n-hexan extracts of Parkia timoriana seeds, Ruta angustifolia leaves, and Parameria barbata stem shell could not also inhibit $S$. aureus, M. luteus, and $S$. typhosa growth.

d. Antibacterial activity of water and water-ethanol extract of fresh pangium

Based on the categorization of antibacterial activity of the extracts (Morales 2003 in Ismaini, 2007), the antibacterial activity of water extract of fresh pangium we "e medium against $S$. aureus, low to medium against $E$. aerogenes, and low against $M$. luteus, $A$. eutrophus, $P$. fluorescens, S. marcescens, F. gleum, and S. typhimurium. Meanwhile, the antibacterial activity of water-ethanol extracts were medium to high activity against $S$. aureus, $A$. eutrophus, and $E$. aerogenes, and low against $M$. Iuteus, P. fluorescens, S. marcescens, F. gleum, and S. typhimurium. El Astal et al. (2005) showed that water extract of Thymus vulgaris had high antibacterial activity against S. aureus, and Pseudomonas aeruginosa while Digrak et al. (1999) showed that Phlomis bourgei extract had high activity against Bacillus subtilis, $S$. aureus, $E$. coli, $P$. aeruginosa, and Proteus vulgaris.

e. Minimum inhibitory concentration of water and water-ethanol extract of fresh pangium

The minimum inhibitory concentration of fresh pangium water extract were $3.49 \mathrm{mg} / \mathrm{mL}$ against $P$. fluorescens and between $8-9 \mathrm{mg} / \mathrm{mL}$ against $S$. aureus, $M$. luteus, and $E$. aerogenes. The minimum inhibitory concentration against $A$. eutrophus, $F$. gleum, S. marcescens, and S. typhimurium were somewhat higher, reaching more than $10 \mathrm{mg} / \mathrm{mL}$ (Table 1). Based on the minimum inhibitory concentration values, water extract of fresh pangium at concentration of about $4 \mathrm{mg} / \mathrm{mL}$ was effective enough to inhibit $P$. fluorescens, but for other species, higher extract concentration is needed. El Astal et al. (2005) reported that water extract of Thymus vulgaris could inhibit $S$. aureus at minimum inhibitory concentration value of $2.5 \mathrm{mg} / \mathrm{mL}$, E. coli of $20 \mathrm{mg} / \mathrm{mL}$, S. typhi of $10 \mathrm{mg} /$ $\mathrm{mL}$, and $P$. aeruginosa at minimum inhibitory concentration value of $20 \mathrm{mg} / \mathrm{mL}$.

The minimum inhibitory concentration of fresh pangium water-ethanol extract were $6-7 \mathrm{mg} / \mathrm{mL}$ against $S$. aureus, A. eutrophus, and $E$. aerogenes, and $8-10 \mathrm{mg} / \mathrm{mL}$ against $F$. gleum and $S$. marcescens, and more than $10 \mathrm{mg} / \mathrm{mL}$ against $P$. fluorescens, $M$. luteus, and S. typhimurium (Table 1). Salvat et al. (2001) stated that water-ethanol extract of Vassobia breviflora was effectively suppress $S$. aureus at minimum inhibitory concentration of $0.25 \mathrm{mg} / \mathrm{mL}$, while for $P$. aeruginosa and $S$. typhimurium, the inhibition was at minimum inhibitory concentration of $1 \mathrm{mg} / \mathrm{mL}$ respectively.

Table 1. Minimum inhibitory concentration of water and water-ethanol extract of fresh pangium seed against various species of bacteria

\begin{tabular}{lccccc}
\hline Kinds of bacteria & $\begin{array}{c}\text { Water extract } \\
(\mathrm{mg} / \mathrm{mL})\end{array}$ & $\begin{array}{c}\text { Water-ethanol } \\
\text { extract } \\
(\mathrm{mg} / \mathrm{mL})\end{array}$ & Kinds of bacteria & $\begin{array}{c}\text { Water extract } \\
(\mathrm{mg} / \mathrm{mL})\end{array}$ & $\begin{array}{c}\text { Water-ethanol } \\
\text { extract } \\
(\mathrm{mg} / \mathrm{mL})\end{array}$ \\
\hline M. luteus & 9.57 & 10.35 & P. fluorescens & 3.49 & 10.54 \\
S. aureus & 8.39 & 7.17 & E. aerogenes & 9.70 & 6.04 \\
S. marcescens & 10.87 & 9.83 & S. typhimurium & 11.73 & 10.11 \\
F. gleum & 10.51 & 8.08 & A. eutrophus & 10.44 & 7.14 \\
\hline
\end{tabular}




\section{CONCLUSION}

1. Water-ethanol extract of fresh and fermented pangium seed produced the higher yield $(5,45$ and $20,53 \mathrm{~g}$ respectively) than that produced by other kinds of solvent, i.e. water and $n$-hexane.

2. Water and water-ethanol extracts of fresh seed showed an effective antibacterial activity against gram positive and negative bacteria at concentration of $40-80 \mathrm{mg} / \mathrm{mL}$, but $\mathrm{n}$-hexane extract didn't show any antibacterial activity at all concentration (10-80 $\mathrm{mg} / \mathrm{mL}$ ).

3. Water, water-ethanol, as well as n-hexane extract of fermented seed didn't show any antibacterial activity against gram positive or negative at all concentration $(10-80 \mathrm{mg} / \mathrm{mL})$.

4. Water extract of fresh seed showed high antibacterial activity against $P$. fluorescens with the minimum inhibitory concentration of $3.49 \mathrm{mg} /$ $\mathrm{mL}$, while the water-ethanol extract showed medium to high antibacterial activity against $S$. aureus and $E$. aerogenes with the minimum inhibitory concentration of 7.17 and $6.04 \mathrm{mg} / \mathrm{mL}$ respectively.

\section{RECOMMENDATIONS}

Though traditionally, pangium kernel has been widely employed as spices, yet, to be accepted in preservation of fish and fish product in areas where pangium has not been popular is not easy. Further studies are important to provide the maximum benefit of pangium as preservative, especially by characterizing the active substances of pangium that responsible to prolong the shelf life of wet fish as well as developing method of industrialization, whether in crude or pure basis.

\section{ACKNOWLEDGEMENT}

This study is assessment on the use of hazardous material in fish handling and the development of better and proper technology in 2007 funded by the Marine and Fisheries Product Processing and Biotechnology. Jakarta.

\section{REFERENCES}

Adidjaja, I. 1991. Activity of Natural Antioxidants from Fermented Pangium Seed in Palm Oil. Bogor Institute of Agriculture. Bogor.
Andarwulan, N., D. Fardiaz, G. A. Wattimena, \& K Shetty. 1999. Antioxidant activity associated with lipid and phenolic mobilization seed germination of Pangium edule Reinw. J. Agric. Food. Chem. 47: 3,158-3,163.

Anwar, E. 1992. Isolation of Antioxidant from Fermented Pangium Seeds. Master of Science Program. Bogor Institute for Agriculture. Bogor.

Bishop, R. 1997. The Football Fruit. FFPN Developer Palau Community Action Agency. Koror. Republic of Palau. $232 \mathrm{pp}$.

Claeson, P., U. Goeransson, S. Johansson, T. Luijendik, \& L. Bohlin. 1998. Fractination protocol for the isolation of polypeptides from plant biomass. J. Nat. Prod. 61: 77-81.

D. G. of Drug \& Food Control. 1995. Indonesian Farmacope. $4^{\text {th }}$ ed. Min. of Health. 1,290 pp.

Dicko, M. H., H. Gruppen, A. S. Traore, A. G. J voragen, \& W. I H. Van Berkel. 2006. Phenolic compounds and related enzymes as determinants of sorghum for food use. Biotechnology and Molecular Biology Reviews. Academic Journals. 1(1): 21-38.

Digrak, M., A. Ilcim, M. H. Alma, \& S. Sen. 1999. Antimicrobial activities of the extracts of various plants (Valex, mimosa bark, gallnut powders, Salvia sp., and Phlomis sp.). Tr. J. of Biology. 23: 241-248.

El Astal, Z. Y., A. E. R. A. Ashour, \& A. A. M. Kerrit. 2005. Antimicrobial activity of some medicinal plants extract in Palestine. Pak. Journal Med. Sci. 21 (2): 187-193.

Gilbert, P. 1984. The revival of microorganism sublethally injured by chemical inhibitors dalam M. H. E. Andrew \& A. D. Russel (ed.). The Revival of Injured Microbes. Academic Press. London. 175-197.

Heruwati, E. S., J. T. Murtini, N. Indriati, F. Ariyani, N. Aji, Dwiyitno, \& Y. Yennie. 2004. Research on the safety of fisheries product during handling and processsing. Technical Report 2004. Research Center for Marine and Fisheries of Product Processsing and Biotechnology.

Heruwati, E. S., H. E. Widyasari, \& J. Haluan. 2007. Preservation of fresh fish preservation using 
Pangium kernel. J. of Mar. and fish Postharvest and Biotechnology. 2 (1): 9-18.

Harborne, J. B. 1998. Phytochemical methods. A Guide to Modern Techniques of Plants Analysis. Third edition. Chapman \& Hall. London. 302 pp.

Heyne, K. 1959. De Nuttige Planten Van Indonesia. Bandung. Van Hoeve.

Hilditch, T. P. \& P. N. Williams. 1964. The Chemical Constituent of Natural Fats. Chapman and Hall. London.

Indriyanto, T. 2004. Screening of phenolic compound and antibacterial test of water, ethanol, methanol, and $\mathrm{n}$-hexane of Parameria barbata and Ruta angustifolia. Thesis PPS Biology. FMIPA UI. 56 $\mathrm{pp}$.

Ismaini, L. 2007. Study on activity and antibacterial analysis of pangium extract. Thesis FMIPA. 95 $\mathrm{pp}$

Moshi, M. J. \& Z. H. Mbwambo. 2005. Some pharmacological properties of extracts of Terminalia sericea roots. Journal Ethnopharm. 97: 43-47.

Nuraida, L., N. Andarwulan, \& E. Kristikasari. 2000 Antimicrobial activity of fresh and fermented Picung (Pangium edule Reinw) seed against pathogenic and food spoilage bacteria. Journal of Food Technoloy and Industry. 4 (2): 18-26

Panghegar, H. 1990. Isolation of Component of Natural Antioxydant from Pangium kernel. Faculty of Agricultural Technology. Bogor Institute for Agriculture. Bogor.

Pimia, R. P., L. Nohynek, C. Meier, M. Kahkonen, M. Heinonen, A. Hopia, \& K. M. O. Caldentey. 2001.
Antimicrobial properties of phenolic compouds from berries. Journal of Applied Microbiology. 90: 494507.

Priyono, R. E. 2004. Skrining golongan senyawa kimia dan uji antibakteri ekstrak etanol $50 \%$ dan nheksana biji kedawung (Parkia timoriana Merr.), daun inggu (Ruta angustifolia L.), dan kulit kayu rapat (Parameria barbata Schum.) terhadap bakteri gram positif. Thesis PPS Biologi. FMIPA UI. $68 \mathrm{pp}$.

Puspitasari-Nienaber, N. L., K. Aitzetmuller, \& G. Werner. 1994. Analytical Investigation on Pangium Edule Seed Oil. Langfassung Publication Stand 20.12.94

Romlah, E. 1992. Study on the Development of Antioxidant and Fat During the Fermentation of Pangium Kernel. Faculty of Agricultural Technolngy. Bogor Institute for Agriculture. Bogor.

Salvat, A., L. Antonnacci, R. H. Fortunato, E. Y. Suarez, \& H. M. Godoy. 2001. Screening of some plants from Northern Argentina for their antimicrobial activity. Letters in Applied Microbiology. 32: 293-297.

Sampurno. 2006. Press Release Head of National Agency of Drug and Food Control Republic Indonesia No.Kh.00.01.1.241.002 Regarding Formalin Misuse for Preservative in Wet Noodle, Soy Cake (Tofu) and Fishes Products. 3 January 2006. http://www.pom.go.id/public/ press release/ detail. asp?id $=24 \& q s$ menuid $=7$. Accessed on Febuary 21, 2007

Wahyono, S. 2004. Isolation and identification of Scurrula atropurpurea as a marking compound. Report Research of Agency for Research and Development of Health. Min. of Health. 16 pp. 


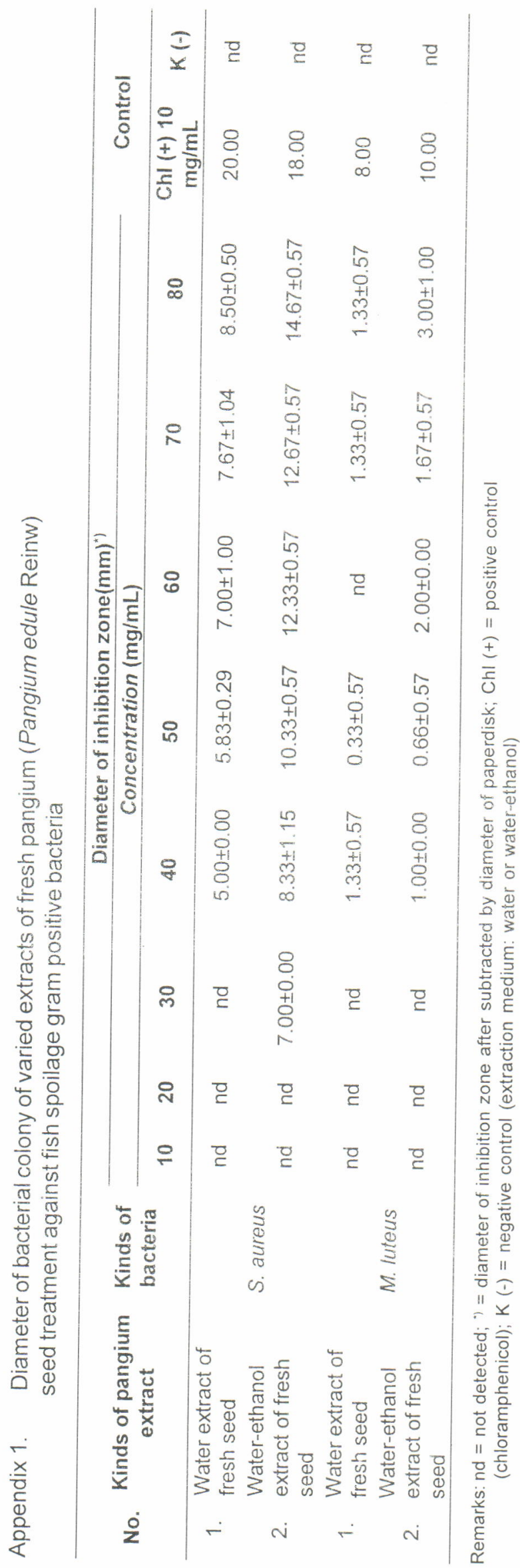


Antibacterial Test of Pangium ..... of Fish Spoilage Bacteria (Heruwati, E. S., et al.)

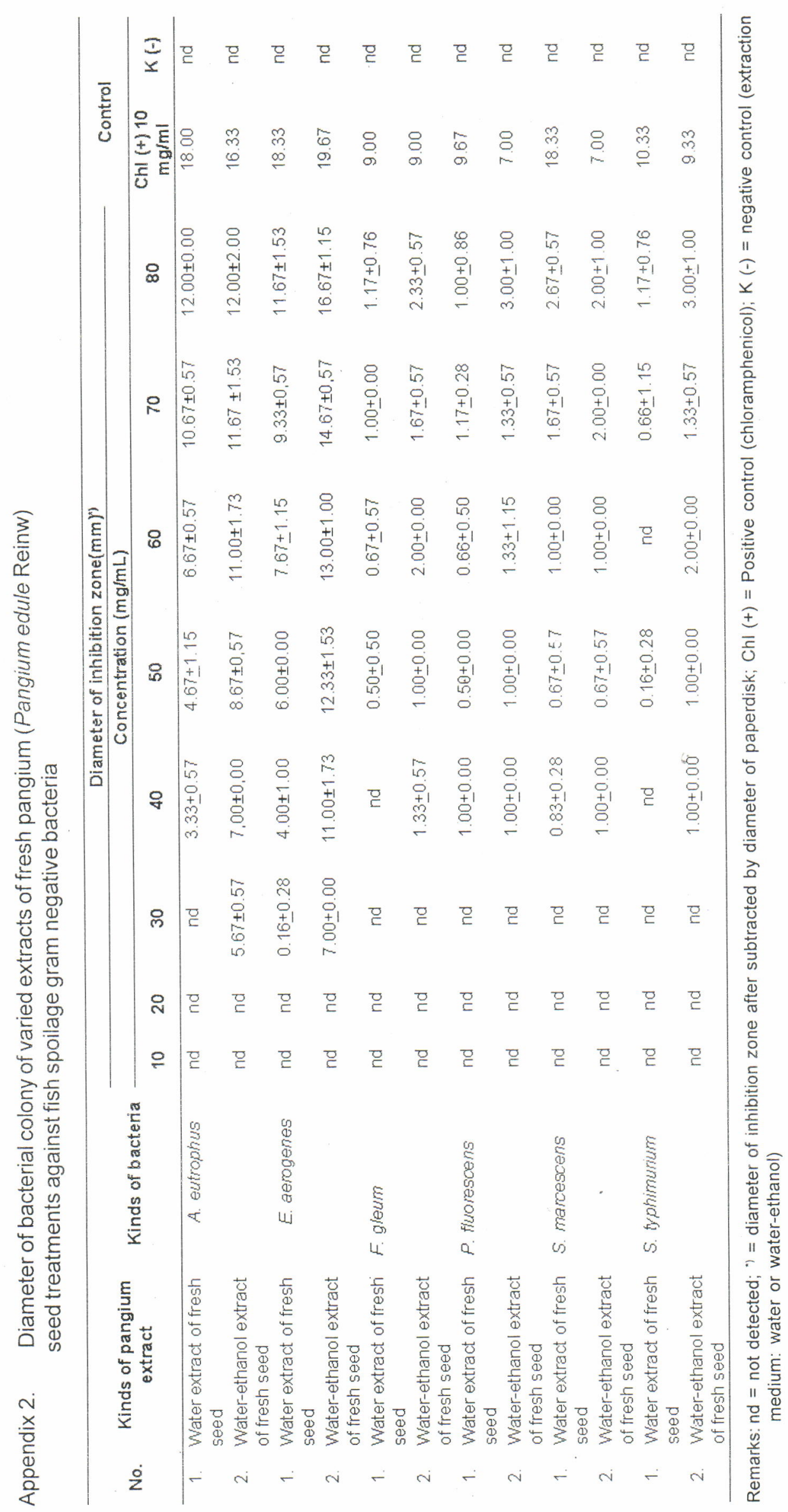


